\title{
Analisis Pengelolaan Sampah Rumah Tangga Berbasis Masyarakat Di Kecamatan Marpoyan Damai Kota Pekanbaru
}

\author{
Lita Febriani*, Yusni Ikhwan Siregar, Ridwan Manda Putra \\ Pascasarjana Ilmu Lingkungan, Program Pascasarjana Universitas Riau, Pekanbaru, \\ CoresspondenceEmail: litafebriani36@gmail.com
}

\begin{abstract}
The purpose of this study is to analyze the factors in community-based waste management and analyze the environmental, economic and social impacts of waste management in Marpoyan Damai District, Pekanbaru City. The approach of this research is quantitative analytic with cross sectional research design. The population in this study were all family heads in the Tangkerang Barat sub-district Marpoyan Damai Pekanbaru City as many as 4,345 households with a sample of 98 people. The results of this study are there is an influence between education ( $p$ value $=0.006)$, infrastructure $(p$ value $=0.003)$, knowledge $(p$ value $=0,000)$ with community participation in household waste management in Marpoyan Damai District, Pekanbaru City. The logistic regression analysis results found that the education variable has a value of $p=0.048$ and an OR 2.888 which means that education has 2 times the risk of waste management. Infrastructure variable has a value of $p=0.001$ and OR 6.838 which means that infrastructure has 6 times the risk of waste management. Knowledge variable has a value of $p=0,000$ and $O R$ 9,617 which means knowledge has 9 times the risk of waste management. The environmental impact of proper waste management is decreasing the volume of waste generation and environmental damage. Economically, there is currently no economic value to waste management, other than the public does not understand waste management that has economic value with $3 R$. Inadequate waste management causes low levels of public health, so people need to pay more for treatment. Socially, most people do not care about waste management and even though there is waste management it is still individual and not organized in an integrated way.
\end{abstract}

Keywords: Education, Infrastructure, Knowledge

Received: 3 Agust 2020, Accepted : October 2020 - Jurnal Photon Vol.11 No.1

DOI : https://doi.org/10.37859/jp.v17i1.2089

PHOTON is licensed under a Creative Commons Attribution-ShareAlike 4.0 International 


\section{Introduction}

Menurut perkiraan, volume sampah yang dihasilkan perorang rata-rata sekitar 0,5 kg/kapita/hari. Jadi, untuk kota besar seperti Pekanbaru yang penduduknya lebih dari 1 juta jiwa, sampah yang dihasilkan sekitar 500 ton/hari. Dengan jumlah yang tergolong besar tersebut, maka perl u ad any a penanganan sampah yang khusus. Bila tidak cepat ditangani secara benar maka kota Pekanbaru akan tenggelam dalam timbunan sampah bersamaan dengan segala dampak negatif yang ditimbulkan (Hasibuan, 2016). Sampah rumah tangga merupakan salah satu jenis sampah yang turut memberberat masalah sampah di Kota Pekanbaru. Saat ini hampir seluruhnya mengalami kesulitan dalam mendapatkan lahan sebagai tempat pembuangan akhir. Masalah sampah rumah tangga tidak dapat diselesaikan sendiri oleh pemerintah. Masyarakat sudah saatnya berperan aktif dal am menangani sampah. Pengelolaan sampah rumah tangga sebaiknya dimulai dari sum bernya, yaitu di rumah tangga. Setiap rumah tangga perlu mengelola sampahnya baik secara individu maupun secara kelompok di lingkungan tempat tinggal masing-masing (Munawir, 2015). Kecamatan Marpoyan Damai merupakan salah satu Kecamatan yang ada di Kota Pekanbaru. Berdasarkan laju timbulan sampah permukiman di Kota Pekanbaru, laju paling tinggi untuk jenis permukiman sederhana berada di Kecamatan Marpoyan Damai yaitu sebesar 2,38 liter/ orang/ hari (Dinas Pertamanan Kota Pekanbaru, 2019). Pengelolaan Sampah Berbasis Masyarakat (PSB M) adalah suatu pendekatan pengelolaan sampah yang didasarkan pada kebutuhan dan permintaan masyarakat, direncanakan, dilaksanakan (jika memungkinkan), dikendalikan dan dievaluasi bersama masyarakat. Dikatakan berbasis masyarakat jika keputusan ditangan masyarakat secara keseluruhan serta tanggung jawab operasi dan pemeliharaannya di tangan masyarakat sesuai dengan kesepakatan. Kalau disederhanakan, PSBM adalah sistem penanganan sampah yang direncanakan, disusun, dioperasikan, dikelola dan dimiliki oleh masyarakat. Dalam pengertian ters ebut, pemeran utama dalam pengelolaan sampah adalah masyarakat. Pemerintah dan lem baga lainnya sebagai motivator dan fasilitator (Munawir, 2015).

Pengelolaan sampah berbasis masyarakat menggunakan konsep 5M, yaitu mengurangi sampah, memilah sampah, memanfaatkan sampah, mendaur ulang sampah dan menabung sampah. Manfaat sistem pengelolaan sampah $5 \mathrm{M}$ dari aspek lingkungan yaitu berkurangnya jumlah sampah yang harus dibuang ke TPA, membantu mengurangi pencemaran udara akibat pembakaran sampah, dan membantu menciptakan lingkungan yang sehat dan bersih). Manfaat dari aspek pendidikan yaitu menanamkan pentingnya mengelola sampah rumah tangga kepada masyarakat dengan cara diinvestasikan atau ditabung, melakukan pendidikan lingkungan hidup sejak dini terhadap anakanak dengan tidak meninggalkan tumbuh kembang mereka, anak-anak akan memahami pentingnya menabung dan anak-anak akan memaknai sampah yang mereka hasilkan. Dari aspek sosial ekonomi yaitu menambah pendapatan keluarga dari sampah yang mereka tabung di bank sam pah, mengubah persepsi negatif yang berkembang di masyarakat terhadap penggiat sampah terutama pemulung. Sistem pengelolaan sampah rumah tangga di Kecamatan Marpoyan Damai terjadi karena tidak adanya kesadaran dari masyarakat untuk berpartisipasi dalam mengelola sampah dan ti dak adanya infrastruktur yang mendukung dalam hal ini yaitu tempat pembuangan sampah sementara, mobil sampah dan gerobak sampah yang disediakan oleh pemerintah setempat. Menumpuknya sampah di Kecamatan Marpoyan Damai ini tidak lepas dari peran pemerintah dan warga setem pat yang membiarkan sampah menumpuk. tumpukan sampah tersebut sudah ada sejak lama. Tujuan penelitian ini adalah 1) Menganalisis faktor-faktor dalam pengelolaan sampah berbasis masyarakat di Kecamatan Marpoyan Damai Kota Pekanbaru. 2) Menganal isisdampak lingkungan, ekonomi dan sosial pengelolaan sampah di Kecamatan Marpoyan Damai Kota Pekanbaru.

\section{The Methods}

Penelitian ini dilaksanakan di Kelurahan Tangkerang Barat Kecamatan Marpoyan Damai Kota Pekanbaru dari bulan Juni-Juli 2020.Pendekatan penelitian ini adalah analitik kuantitatif dengan rancangan penelitian cross sectional. Populasi dalam penelitian ini adalah seluruh Kepala Kel uarga

Received: 3 Agust 2020, Accepted : October 2020 - Jurnal Photon Vol.11 No.1

DOI : https://doi.org/10.37859/jp.v17i7.2089

PHOTON is licensed under a Creative Commons Attribution-ShareAlike 4.0 International 
(KK) yang ada di Kelurahan Tangkerang Barat Kecamatan Marpoyan Damai Kota Pekanbaru yaitu sebanyak 4.345 dengan jumlah sampel sebanyak 98 orang. Jenis data yang digunakan yaitu data primeryang diperoleh langsung pada saat penelitian meliputi data tentang usia, pendidikan, pekerjaan, infrastruktur, pengetahuan dan sikap. Sedangkan data sekunder adalah data yang diperoleh dari Kantor Camat Marpoyan Damai dan Dinas Kebersihan Kota Pekanbaru. Analisis data dilakukan dengan analisis univariat, bivariat dan multivariat.

\section{Result and Discussion}

Karakteristik responden berdasarkan variabel dalam penelitian ini dapat dilihat pada Tabel 1 berikut:

Tabel 1 Karakteristik Responden

\begin{tabular}{clcc}
\hline No & \multicolumn{1}{c}{ Variabel } & Frekuensi & Persentase \\
\hline $\mathbf{1}$ & Pengelolaan Sampah & & \\
& Tidak Berpartisipasi & 53 & 54,1 \\
& Berpartisipasi & 45 & 45,9 \\
\hline \multicolumn{2}{c}{ Jumlah } & $\mathbf{9 8}$ & $\mathbf{1 0 0}$ \\
\hline $\mathbf{2}$ & Pendidikan & & \\
& Rendah (SD, SMP) & 69 & 70,4 \\
& Tinggi (SMA, Perguruan Tinggi) & 29 & 29,6 \\
& & $\mathbf{9 8}$ & $\mathbf{1 0 0}$ \\
\hline $\mathbf{3}$ & Infrastrukstur & & \\
& Tidak Tersedia & 52 & 53,1 \\
& Tersedia & 46 & 46,9 \\
& & $\mathbf{9 8}$ & $\mathbf{1 0 0}$ \\
\hline $\mathbf{4}$ & Pengetahuan & & \\
& Kurang & 63 & 64,3 \\
& Baik & 35 & 35,7 \\
& & $\mathbf{9 8}$ & $\mathbf{1 0 0}$ \\
\hline
\end{tabular}

Sumber: Data Primer, 2020

Berdasarkan Tabel 1 menunjukkan bahwa sebagian besar responden tidak berpartisipasi dalam pengelolaan sampah yaitu sebanyak $54,1 \%$ dan $45,9 \%$ berpartisipasi dalam pengelolaan sampah. Hal ini menunjukkan bahwa masyarakat di Kelurahan Tangkerang Barat Kecamatan Marpoyan Damai Kota Pekanbaru sebagian besar tidak berpartisipasi di dalam pengelolaan sampah rumah tangga, karena masyarakat di Kelurahan ini terdiri dari berbagai latar belakang dan suku budaya sehingga tidak semua masyarakat menyadari dan memahami betapa pentingnya kebersihan lingkungan. Kemudian kurangnya partisipasi masyarakat didalam pengelolaan sampah rumah tangga juga dapat diakibatkan kurangnya fasilitas kebersihan seperti tidak terdapatnya TPS, mobil sampah maupun tempat sampah. Fasilitas yang disediakan sendiri oleh masyarakat belum ada pemisahan antara sampah organik dan anorganik.

Sejalan dengan pendapat Hartati (2010) peran serta seseorang dalam suatu kegiatan pembangunan diperoleh oleh banyak faktor, baik faktor lingkunga sosial, budaya, ekonomi maupun faktor lingkungan fisiknya. Semakin baik kondisi lingkungan sosial, budaya dan ekonomi serta lingkungan fisiknya semakin besar peluang seseorang untuk melakukan peran sosial kemasyarakatan lai nnya seperti hal pengelolaan sampah rumah tangga. Hal ini juga sejalan dengan pendapat Artiningsih (2008) rendahnya partisipasi masyarakat disebabkan oleh ketidaktahuan masyarakat serta tidak tersedianya TPS di Kelurahan Tangkerang Barat Kecamatan Marpoyan Damai Kota Pekanbaru.

Tabel 1 menunjukkan bahwa sebagian besar responden memiliki pendidikan rendah (SD, SMP) sebanyak 69 responden $(70,4 \%$ ) dan sisanya 29,6\% memiliki pendidikan tinggi (SM A, Per guruan

Received: 3 Agust 2020, Accepted : October 2020 - Jurnal Photon Vol.11 No.1

DOI : https://doi.org/10.37859/jp.v17i7.2089

PHOTON is licensed under a Creative Commons Attribution-ShareAlike 4.0 International 
Tinggi). Hal ini menunjukkan bahwa masih banyak masyarakat yang memiliki pendidikan rendah di di Kelurahan Tangkerang Barat Kecamatan Marpoyan Damai Kota Pekanbaru.

Angell (2011) pendidikan dikatakan sebagai salah satu syarat mutlak untuk berpartisipasi. Pendidikan dianggap dapat mempengaruhi sikap hidup seseorang terhadap lingkungannya, suatu sikap yang diperlukan bagi peningkatan kesejahteraan seluruh masyarakat. Menurut Sari (2017) pendidikan merupakan upaya untuk meningkatkan pengetahuan dan merubah sikap, sehingga responden yang memiliki pendidikan yang tinggi dapat memiliki perilaku yang baik dalam pengelolaan sampah. Pendidikan yang cukup dalam hal ini adalah kategori tingkat pendidikan SM A akan lebih sadar dalam pengelolaan sampah yang baik seperti masyarakat yang berpendidikan cukup sudah mengupayakan peningkatan pengelolaan sampah melalui bank sampah (Setyaningrum, 2015).

Berdasarkan Tabel 1 menunjukkan bahwa sebagian besar responden tidak memiliki infrastruktur sebanyak 52 responden (53,1\%) dan sisanya memiliki infrastruktur sebanyak 46,9\%. Infrastruktur yang ada umumnya infrastruktur berupa tempat sampah sendiri untuk mengelola sampah rumah tangga tetapi bukan dari pemerintah setempat melainkan diambil oleh masyarakat juga. Sebagian besar rumah tangga meletakkan sampah rumah tangga di pohon atau tiang di halaman rumah mereka. Seiring berkembangnya pemukiman di Kota Pekanbaru akan berimbas pada peningkatan jumlah penduduk dan tingkat konsumsi masyarakat, maka akan meningkat pula pertumbuhan sampah akibat pertumbuhan penduduk yang tidak diimbangi dengan infrastruktur sampah yang memadai. Masyarakat masih menjadikan lahan kosong ataupun pinggir jalan sebagai tempat pembuangan sampah, hal ini dikarenakan masih minimnya infrastruktur pengelolaan sampah seperti TPA. Berdasarkan Tabel 1 menunjukkan bahwa sebagian besar responden memiliki pengetahuan yang kurang sebanyak 63 responden $(64,3 \%)$ dan 35 responden $(35,7 \%)$ memiliki pengetahuan yang baik. Menurut Mulasari (2012) pengetahuan adalah kesan dalam pikiran manusia sebagai hasil dalam penggunaan panca indera, yang berbeda sekali dengan kepercayaan, takhayul, maupun penerapan-penerapan yang keliru.

Pengetahuan tentang pengelolaan sampah diartikan sebagai pengetahuan yang terdiri dari pengertian sampah, jenis sampah, sumber sampah, faktor yang mempengaruhi produksi sam pah, pengaruh sampah terhadap kesehatan masyarakat dan lingkungan, syarat tempat sampah, kegiatan operasional pengelolaan sampah dan alat yang digunakan dalam pengelolaan sampah dan cara membuang sampah (Kamal, 2009).

\section{Pengaruh Pendidikan dalam Pengelolaan Sampah Berbasis Masyarakat di Kecamatan Marpoyan Damai Kota Pekanbaru}

Pengaruh pendidikan dalam pengelolaan sampah berbasis masyarakat di Kecamatan Marpoyan Damai Kota Pekanbarudapat dili hat pada Tabel 4.2 berikut:

Tabel 2 Pengaruh Pendidikan dalam Pengelolaan Sampah Berbasis Masyarakat di Kecamatan Marpoyan Damai Kota Pekanbaru

\begin{tabular}{|c|c|c|c|c|c|c|c|c|}
\hline \multirow{3}{*}{ Pendidikan } & \multicolumn{4}{|c|}{ Partisipasi Masyarakat } & \multirow{2}{*}{\multicolumn{2}{|c|}{ Total }} & \multirow{3}{*}{$\begin{array}{c}\mathrm{P} \\
\text { value }\end{array}$} & \multirow{3}{*}{ OR } \\
\hline & \multicolumn{2}{|c|}{ Tidak Berpartisipasi } & \multicolumn{2}{|c|}{ Berpartisipasi } & & & & \\
\hline & $\mathbf{n}$ & $\%$ & $\mathbf{n}$ & $\%$ & $\mathbf{n}$ & $\%$ & & \\
\hline Rendah & 44 & 63,8 & 25 & $\overline{36,2}$ & 69 & 100 & \multirow{3}{*}{0,006} & 3,911 \\
\hline Tinggi & 9 & 31 & 20 & 69 & 29 & 100 & & $(1,547-$ \\
\hline Total & 53 & 54,1 & 45 & 45,9 & 98 & 100 & & $9,886)$ \\
\hline
\end{tabular}

Berdasarkan Tabel 2 dapat dilihat bahwa dari 69 responden yang memiliki pendidikan rendah, terdapat 44 responden $(63,8 \%)$ yang tidak berpartisipasi dalam pengelolaan sampah. Sedangkan dari 29 responden dengan pendidikan tinggi, terdapat 9 responden (31\%) yang tidak berpartisipasi dalam pengelolaan sampah. Hasil uji statistik chi square didapatkan p value $0,006(<0,005)$ yang berarti ada pengaruh antara pendidikan dengan partisipasi masyarakat dalam pengelolaan sampah

Received: 3 Agust 2020, Accepted : October 2020 - Jurnal Photon Vol.11 No.1

DOI : https://doi.org/10.37859/jp.v17i7.2089

PHOTON is licensed under a Creative Commons Attribution-ShareAlike 4.0 International 
rumah tangga di Kecamatan Marpoyan Damai Kota Pekanbaru. Nilai OR yaitu 3,911 yang artinya pendidikan berpengaruh terhadap partisipasi masyarakat dalam pengelolaan sampah rumah tangga sebanyak 3 kali.

Hal ini sejalan dengan penelitian oleh Damiati (2015) yang mana tingkat pendidikan baik formal maupun non formal dapat mencerminkan tindakan dalam pengelolaah sampah rumah tangga. Pendidikan adalah usaha sadar dan terencana untuk menjadikan suasana belajar dan proses pembelajaran agar peserta didik secara aktif mengembangkan potensi dirinya untuk memiliki kekuatan spiritual keagamaan, pengendalian diri, kepribadian, kecerdasan, akhlak mulia, serta keterampilan yang diperlukan dirinya, masyarakat, bangsa dan negara. Pendidikan merupakan upaya untuk meningkatkan pengetahuan dan merubah sikap, sehingga responden yang memiliki pendidikan yang tinggi memiliki perilakuyang baik dalam pengelolaan sampah. Tetapi pendidi kan yang tinggi tidak menjamin perilaku pengelolaan sampahnya baik (Sari, 2017).

Dalam penelitian ini tingkat pendidikan yang digunakan adalah pendidikan menurut Sari (2017) yaitu pendidikan rendah dan pendidikan tinggi. Menurut Asmawati (2010) mengemukakan bahwa tingginya tingkat pendidikan seseorang dapat menyerap informasi lebih mudah dan lebih baik dari beberapa sumber oleh karena dimiliki kemampuan mencerna informasi-informasi tersebut sehingga lebih mudah untuk mengerti dan menyadari suatu hal.Angell (2011) pendidikan dikatakan sebagai salah satu syarat mutlak untuk berpartisipasi. Pendidikan dianggap dapat mempengaruhi sikap hidup seseorang terhadap lingkungannya, suatu sikap yang diperlukan bagi peningkatan kesejahteraan seluruh masyarakat.Pendidikan yang cukup dalam hal ini adalah kategori tingkat pendidikan SMA akan lebih sadar dalam pengelolaan sampah yang baik seperti masyarakat yang berpendidikan cukup sudah mengupayakan peningkatan pengelolaan sampah melalui bank sampah (Setyaningrum, 2015).

Pengaruh Infrastruktur dalam Pengelolaan Sampah Berbasis Masyarakat di Kecamatan Marpoyan Damai Kota Pekanbaru

Pengaruh infrastruktur dalam pengelolaan sampah berbasis masyarakat di Kecamatan Marpoyan Damai Kota Pekanbarudapat dilihat pada Tabel 3 berikut:

Tabel 3 Pengaruh Infrastruktur dalam Pengelolaan Sampah Berbasis Masyarakat di Kecamatan Marpoyan Damai Kota Pekanbaru

\begin{tabular}{|c|c|c|c|c|c|c|c|c|}
\hline \multirow{3}{*}{ Infrastruktur } & \multicolumn{4}{|c|}{ Partisipasi Masyarakat } & \multirow{2}{*}{\multicolumn{2}{|c|}{ Total }} & \multirow{3}{*}{$\stackrel{\mathrm{P}}{\text { value }}$} & \multirow{3}{*}{ OR } \\
\hline & \multicolumn{2}{|c|}{ Tidak Berpartisipasi } & \multicolumn{2}{|c|}{ Berpartisipasi } & & & & \\
\hline & $\mathbf{n}$ & $\%$ & $\mathbf{n}$ & $\%$ & $\mathbf{n}$ & $\%$ & & \\
\hline Tidak te & 36 & 69,2 & 16 & 30,8 & 52 & 100 & \multirow{3}{*}{0,003} & 3,838 \\
\hline Tersedia & 17 & 37 & 29 & 63 & 46 & 100 & & $(1,657-$ \\
\hline Total & 53 & 54,1 & 45 & 45,9 & 98 & 100 & & $8,889)$ \\
\hline
\end{tabular}

Berdasarkan Tabel 3 dapat dilihat bahwa dari 52 responden yang tidak memiliki infrastruktur, terdapat 36 responden $(69,2 \%)$ yang tidak berpartisipasi dalam pengelolaan sampah. Sedangkan dari 46 responden dengan infrastruktur, terdapat 17 responden (37\%) yang tidak berpartisipasi dalam pengelolaan sampah. Hasil uji statistik chi square didapatkan p value $0,003(<0,005)$ yang berarti ada pengaruh antara infrastruktur dengan partisipasi masyarakat dalam pengelolaan sampah rumah tangga di Kecamatan Marpoyan Damai Kota Pekanbaru. Nilai OR yaitu 3,911 yang artinya infrastruktur berpengaruh terhadap partisipasi masyarakat dalam pengelolaan sampah rumah tangga sebanyak 3 kali.

Hal ini sejalan dengan penelitian oleh Manalu (2013) di Kelurahan Binjai Kecamatan Medan D enai Kota Medan menyatakan bahwa semakin baik tersediaan tempat sampah seperti mempunyai tempat pembuangan sampah di rumah dengan melakukan pemilahan sampah rumah tangga, $m$ aka akan semakin baik pula partisipasinya. Hal ini juga sejalan dengan penelitian Lestari (2018) bahwa

Received: 3 Agust 2020, Accepted : October 2020 - Jurnal Photon Vol.11 No.1

DOI : https://doi.org/10.37859/jp.v17i7.2089

PHOTON is licensed under a Creative Commons Attribution-ShareAlike 4.0 International 
ketersediaan sarana yang disertai dengan pengetahuan yang baik akan meningkatkan partisipasi masyarakat dalam mengelola lingkungan khususnya mengenai sampah.

Hal ini sejalan dengan pendapat Yolarita dalam Tansatrisna (2014), ketersediaan sarana dan prasarana merupakan faktor yang penting bagi pengelolaan sampah rumah tangga. Pemerintah tidak menyediakan infrastruktur sampah secara merata sehingga masyarakat menyediakan mobil pengangkut sampah sendiri dengan membayar retribusi tiap bulannya. Sebagian masyarakat memilih membuang sampah ke pinggir jalan, TPS yang terletak agak jauh dari rumah atau membakar sampah rumah tangganya.

Pengaruh Pengetahuan dalam Pengelolaan Sampah Berbasis Masyarakat di Kecamatan Marpoyan Damai Kota Pekanbaru

Pengaruh pengetahuan dalam pengelolaan sampah berbasis masyarakat di Kecamatan Marpoyan Damai Kota Pekanbarudapat dilihat pada Tabel 4 berikut:

Tabel 4 Pengaruh Pengetahuan dalam Pengelolaan Sampah Berbasis Masyarakat di Kecamatan Marpoyan Damai Kota Pekanbaru

\begin{tabular}{|c|c|c|c|c|c|c|c|c|}
\hline \multirow{3}{*}{ Pengetahuan } & \multicolumn{4}{|c|}{$\begin{array}{l}\text { Partisipasi Masyarakat } \\
\end{array}$} & \multirow{2}{*}{\multicolumn{2}{|c|}{ Total }} & \multirow{3}{*}{$\begin{array}{c}\mathrm{P} \\
\text { value }\end{array}$} & \multirow{3}{*}{ OR } \\
\hline & \multicolumn{2}{|c|}{ Tidak Berpartisipasi } & \multicolumn{2}{|c|}{ Berpartisipasi } & & & & \\
\hline & $\mathbf{n}$ & $\%$ & n & $\%$ & $\mathbf{n}$ & $\%$ & & \\
\hline Kurang & 44 & 69,8 & 19 & 30,2 & 63 & 100 & \multirow{3}{*}{0,000} & 6,69 \\
\hline Baik & 9 & 25,7 & 26 & 74,3 & 35 & 100 & & $(2,641-$ \\
\hline Total & 53 & 54,1 & 45 & 45,9 & 98 & 100 & & 16,948) \\
\hline
\end{tabular}

Berdasarkan Tabel 4 dapat dilihat bahwa dari 63 responden yang memiliki pengetahuan kurang, terdapat 44 responden $(69,8 \%)$ yang tidak berpartisipasi dalam pengelolaan sampah. Sedangkan dari 35 responden dengan pengetahuan baik, terdapat 9 responden $(25,7 \%)$ yang tidak berpartisipasi dalam pengelolaan sampah. Hasil uji statistik chi square didapatkan $\mathrm{p}$ value 0,000 $(<0,005)$ yang berarti ada pengaruh antara pengetahuan dengan partisipasi masyarakat dalam pengelolaan sampah rumah tangga di Kecamatan Marpoyan Damai Kota Pekanbaru. Nilai OR yai tu 6,69 yang artinya pengetahuan berpengaruh terhadap partisipasi masyarakat dalam pengelolaan sampah rumah tangga sebanyak 6 kali.

Hal ini sejalan dengan penelitian oleh Dedi (2014) di Desa Loli Tasiburi Kabupaten Donggala menyatakan bahwa banyaknya semakin tinggi pengetahuan masyarakat tentang pengelolaan sampah maka akan semakin tinggi partisi pasi masyarakat dalam pengelolaan sampah. Bany aknya pengetahuan baik di masyarakat disebabkan oleh faktor pendidikan dan komunikasi masy arakat. Karena masyarakat yang berpendidikan tinggi dapat lebih mudah memahami informasi yang diterima.

Pengetahuan tentang pengelolaan sampah dapat diperoleh melalui pendidikan maupun lingkungan. Pengetahuan yang diperoleh dari lingkungan misalnya dari lingkungan tempat tinggal seperti keluarga, tetangga dan teman sebaya. Selain itu pengalaman juga dapat mempengaruhi tingkat pengetahuan seseorang. Tingkat pengetahuan dapat mempengaruhi pola pikir dan kesadaran. Semakin tinggi tingkat pengetahuan masyarakat maka akan semakin baik dan tinggi pula kesadaran masyarakat. Oleh karena itu pengetahuan masyarakat juga dapat diasumsikan sebagai faktor yang dapat mempengaruhi tingkat partisipasi.

Faktor yang Paling Dominan dalam Pengelolaan Sampah Berbasis Masyarakat di Kecamatan Marpoyan Damai Kota Pekanbaru

Untuk mengetahui faktor yang paling dominan dalam pengelolaan sampah berbasis masyarak at di Kecamatan Marpoyan Damai Kota Pekanbaru dilakukan analisis multivariat. Sebelum dilakukan analisis multivariat maka dilakukan seleksi bivariat. Seleksi bivariat merupakan penentuan variabel independen potensial (variabel kandidat) yang akan masuk ke dalam analisis multivariat.

Received: 3 Agust 2020, Accepted : October 2020 - Jurnal Photon Vol.11 No.1

DOI : https://doi.org/10.37859/jp.v17i7.2089

PHOTON is licensed under a Creative Commons Attribution-ShareAlike 4.0 International 
Ditetapkan variabel kandidat dalam analisis bivariat yaitu variabel yang memiliki nilai $\mathrm{p}$ value $<0,25$. Nilai OR yang diperoleh dari hasil uji chi squareti daklah murni sebagai faktor risiko, namun masih ada pengaruh dari variabel confonding, sehingga faktor risiko yang memenuhi nilai kemaknaan $p<0,25$ diikutkan dalam pemodelan. Variabel tersebut adalah pendidikan, pengetahuan dan infrastruktur.

Hasil seleksi pada variabel dependen menghasilkan beberapa variabel dependen yang masuk dalam pemodelan adalah pendidikan, pengetahuan dan infrastruktur. Oleh karena itu, variabel tersebut akan diikutkan dalam uji regresi logistik. Selanjutnya dilakukan uji regresi logistik. Setelah dilakukan seleksi beberapa tahap terhadap variabel-variabel tersebut, maka didapatkan hasil pemodelan akhir. Hasil pemodelan akhir ini dilihat dengan melihat nilai $\mathrm{p}$ terkecil (yang paling signifikan).Hasil uji regresi logistik partisipasi masyarakat dalam pengelolaan sampah rumah tangga dapat dilihat pada Tabel 4.6:

Tabel 5 Pengaruh Hasil Nilai Seleksi pada Variabel Dependen Pengelolaan Sampah Berbasis Masyarakat di Kecamatan Marpoyan Damai Kota Pekanbaru

\begin{tabular}{lrrrrrl}
\hline \multirow{2}{*}{ Variabel } & \multirow{2}{*}{ B } & \multirow{2}{*}{ Sig. } & \multirow{2}{*}{ OR } & \multicolumn{2}{c}{ 95\% C.I for OR } & \multirow{2}{*}{ Keterangan } \\
\cline { 5 - 6 } & & & & Lower & Upper & \\
\hline Pendidikan & 1,060 & 0,048 & 2,888 & 1,012 & 8,242 & Berpengaruh \\
Infrastruktur & 1,923 & 0,001 & 6,838 & 2,280 & 20,507 & Berpengaruh \\
Pengetahuan & 2,264 & 0,000 & 9,617 & 3,063 & 30,201 & Berpengaruh \\
Constant & $-2,276$ & & & & & \\
\hline
\end{tabular}

BerdasarkanTabel 5 dapat terlihat hasil pemodelan terakhir dalam penelitian ini, variabel yang paling berhubungan secara signifikan dengan pengelolaan sampah berbasis masyarakat di Kecamatan Marpoyan Damai Kota Pekanbaru adalah variabel pendidikan, infrastruktur dan pengetahuan.

Berdasarkan Tabel 5 dapat dilihat bahwa variabel pendidikan memiliki nilai $\mathrm{p}=0,048$ dan OR 2,888 yang artinya pendidikan memiliki 2 kali risiko terhadap pengelolaan sampah. Variabel infrastruktur memiliki nilai $p=0,001$ dan OR 6,838 yang artinya infrastruktur memiliki 6 kali risiko terhadap pengelolaan sampah. Variabel pengetahuan memiliki nilai $\mathrm{p}=0,000$ dan $0 \mathrm{R} 9,617$ yang artinya pengetahuan memiliki 9 kali risiko terhadap pengelolaan sampah. Model regresi logistik yang digunakan dalam penelitian ini adalah sebagai berikut: $Y$ (pengelolaan sampah) $=-2,276+1,060$ (pendidikan) + 1,923 (infrastruktur) +2,264 (pengetahuan) + e. Berdasarkan Tabel 4.5 diketahui bahwa faktor yang paling dominan terhadap pengelolaan sampah rumah tangga adalah pengetahuan. Pengetahuan yang dimiliki masyarakat dapat diperoleh melalui lembaga pendidikan formal maupun non formal. Selain itu pengetahuan juga dapat diperoleh dari sumber-sum ber lain seperti pengalaman, lingkungan tempat tinggal dan keluarga. Pengetahuan yang baik akan membuat masyarakat sadar dan peduli akan pentingnya menjaga kebersihan lingkungan serta mau peduli terhadap lingkungan sekitar. Tingkat pengetahuan tidak hanya diperoleh dari suatu proses pembelajaran tetapi juga dari suatu pengalaman. Tingkat pengetahuan seseorang dapat mempengaruhi pola pikir atau tingkat kesadaran. Semakin tinggi tingkat pengetahuan masy arakat maka akan semakin baik dan tinggi pula kesadaran masyarakat. Oleh karena itu pengetahuan masyarakat juga dapat mempengaruhi partisipasi masyarakat.

Partisipasi masyarakat dalam pengelolaan sampah merupakan salah satu faktor teknis untuk menanggulangi persoalan sampah perkotaan atau lingkungan pemukiman dari tahun ke tahun yang semakin kompleks.Reduce atau mengurangi, reuse atau penggunaan kembali dan recyclingatau daur ulang adalah model relatif aplikatif dan dapat bernilai ekonomis.Sistemini diterapkan pada skala kawasan sehingga memperkecil kuantitas dan kompleksitas sampah model ini akan dapat memangkas rantai transportasi yang panjang dan beban APBD yang berat (Hartati, 2010).

Received: 3 Agust 2020, Accepted : October 2020 - Jurnal Photon Vol.11 No.1

DOI : https://doi.org/10.37859/jp.v17i7.2089

PHOTON is licensed under a Creative Commons Attribution-ShareAlike 4.0 International 


\section{Menganalisis Dampak Lingkungan, Ekonomi dan Sosial Pengelolaan Sampah Berbasis Masyarakat di Kecamatan Marpoyan Damai Kota Pekanbaru}

\section{Dampak Lingkungan}

Pengelolaan sampah yang tepat dapat menyebabkan penurunan volume sampah yang ditimbulkan. Masyarakat masih menganggap bahwa sampah merupakan sisa dari sebuah proses yang tidak diinginkan dan tidak mempunyai nilai ekonomis. Berkaitan dengan masal ah timbulan sampah, masih adanya masyarakat yang membuang sampah bukan pada tem patny a terutama di saluran air dan dibakar yang menyebabkan lingkungan menjadi kotor, ti mbul nya berbagai macam penyakit, pencemaran lingkungan dan kerusakan ekosistem.

Pengelolaan sampah adalah pengaturan yang berhubungan dengan pengendalian timbulan sampah, penyimpanan sampah, pemindahan sampah dan pengangkutan sampah, pengolahan dan pembuangan sampah dengan cara merujuk pada dasar-dasar yang terbaik mengenai kesehatan masyarakat, ekonomi, teknik, konservasi, estetika dan pertimbangan lingkungan yang tanggap terhadap perilaku massa. Pengelolaan sampah mempunyai tujuan yang sangat mendasar yang meliputi meningkatkan kesehatan lingkungan dan masyarakat, melindungi sumber daya alam (air), melindungi fasilitas sosial ekonomi dan menunjang sektor s trategi es (Rahardyan dan Widagdo, 2005).

Beberapa penelitian juga dilakukan untuk menentukan prioritas aspek penting yang perlu diperhatikan dalam pengelolaan sampah. Menurut Amurwaraharja (2003:137), dalam rangka menentukan alternatif teknologi pengolahan sampah ada empat aspek yang perlu dipertimbangkan yaitu aspek sosial, ekonomi, lingkungan, dan teknis.Adapun kriteria dari aspek lingkungan dapat dijabarkan menjadi kriteria-kriteria yaitu meminimalisir pencemaran air, meminimalisir pencemaran udara dan bau, meminimalisir pencemaran tanah, meminimalisir habitat bibit penyakit, meminimalisir penurunan estetika/keindahan lingkungan. kesesuaian dengan arahan pengembangan kota.

Salah satu permasalahan yang ditimbulkan dari sampah adalah menurunnya estetika di sekitar tempat pembuangan sampah sehingga berpotensi menimbulkan konflik sosial dengan masyarakat yang ada di sekitarnya. Penentangan yang dilakukan masyarakat sekitar pada umumnya berkenaan dengan sebab yang membahayakan kesehatan, keselamatan, berkurangnya kenyamanan dan keterbatasan lahan khususnya untuk penempatan TPS. Seperti yang diungkapkan oleh Hadi (2005:47), dampak lingkungan dan sosial yang timbul akibat TPS telah menjadi fenomena umum di kota-kota besar dan bahkan menjurus menjadi konflik vertikal. Resistensi terhadap TPS oleh penduduk lokal telah menjadi fenomena umum. Dalam konteks pemecahan persoal an sampah, maka perubahan pola konsumsi merupakan salah satu pendekatan yang harus dimulai. Selain itu, Hadi (2005:18) juga mengatakan bahwa pendekatan pembangunan masyarakat perlu diterapkan dikarenakan banyaknya gejolak-gejolak sosial akibatadanya aktivitas pembangunan.

Manfaat sistem pengelolaan sampah $5 \mathrm{M}$ dari aspek lingkungan yaitu berkurangnya jumlah sampah yang harus dibuang ke TPA, membantu mengurangi pencemaran udara akibat pembakaran sampah, dan membantu menciptakan lingkungan yang sehat dan bersih).

\section{Dampak Ekonomi}

Secara ekonomi, saat ini belum ada nilai ekonomis terhadap pengelolaan sampah, selain masyarakat belum paham terhadap pengelolaan sampah yang mempunyai nilai ekonomis dengan 3R. Sebagian besar kesadaran terhadap pengelolaan sampah masih rendah. Aspek ekonomi dapat dijabarkan menjadi tiga kriteria, yaitu investasi rendah, biaya operasional rendah, menghasilkan pendapatan asli daerah (PAD) yang tinggi. Pengelolaan sampah berbasis masyarakat menggunakan konsep 5M, yaitu mengurangi sampah, memilah sampah, memanfaatkan sampah, mendaur ulang sampah dan menabung sampah. Manfaat dari aspek pendidikan yaitu menanamkan pentingnya mengelola sampah rumah tangga kepada masyarakat dengan cara diinvestasikan atau ditabung, melakukan pendidikan lingkungan

Received: 3 Agust 2020, Accepted : October 2020 - Jurnal Photon Vol.11 No.1

DOI : https://doi.org/10.37859/jp.v17i7.2089

PHOTON is licensed under a Creative Commons Attribution-ShareAlike 4.0 International 
hidup sejak dini terhadap anak-anak dengan tidak meninggalkan tumbuh kembang mereka, anak-anak akan memahami pentingnya menabung dan anak-anak akan memaknai sampah yang mereka hasilkan. Dari aspek ekonomi yaitu menambah pendapatan keluarga dari sampah yang di daur ulang, mengubah persepsi negatif yang berkembang di masyarakat terhadap penggiat sampah terutama pemulung. Pengelolaan sampah yang tidak dapat memadai menyebabkan rendahnya tingkat kesehatan masyarakat sehingga masyarakat perlu mengeluarkan biaya lebih untuk berobat. Selain itu, infrastruktur lain dapat juga dipengaruhi oleh pengelolaan sampah yang tidak memadai, seperti tingginya biaya yang diperlukan untuk pengolahan air. Jika sarana penampung sampah kurang atau tidak efisien, orang akan cenderung membuang sampahnya dijalan. Hal ini mengakibatkan jalan perlu lebih sering dibersihkan dan diperbaiki.

\section{Dampak Sosial}

Secara sosial, sebagian besar masyarakat belum peduli terhadap pengelolaan sampah dan walaupun ada pengelolaan sampah masih bersifat individual dan belum terorganisir secara terpadu, sehingga intensitas kebersamaan dalam komunitas masih sangat rendah.Salah satu manfaat sosial adanya pengelolaan sampah yaitu mampu melibatkan masyarakat. Namun hal ini belum berjalan dengan baik. Selain itu, pengelolaan sampah yang tidak memadai menyebabkan rendahnya tingkat kesehatan masyarakat.

Manfaat pengelolaan sampah dari aspek pendidikan yaitu menanamkan pentingnya mengelola sampah rumah tangga kepada masyarakat dengan cara diinvestasikan atau ditabung Dari aspek sosial yaitu mengubah persepsi negatif yang berkembang di masyarakat terhadap penggiat sampah terutama pemulung.

Menurut Artiningsih (2008),partisipasi masyarakat memiliki pengertian yaitu keterlibatan masyarakat dalam proses penentuan arah strategi dan kebijakan pembangunan yang dilakukan pemerintah dan keterlibatan dalam memikul tanggung jawab dalam pelaksanaan kegiatan pembangunan secara adil dan merata. Sampai saat ini peran serta masyarakat secara umum hanya sebatas pembuangan sampah saja belum sampai pada tahapan pengelolaan sampah yang dapat bermanfaat kembali bagi masyarakat. Pengelolaan sampah yang sederhana dengan memisahkan sampah organik dan anorganik memerlukan sosialisasi yang efektif dari pemerintah kepada masyarakat.

Surjandari et al. (2009:143) meneliti urutan aspek prioritas yang perlu diperhatikan dalam menentukan model pengelolaan sampah yaitu aspek sosial, lingkungan, ekonomi dan priori tas terakhir adalah teknologi. Kriteria dari aspek sosial diantaranya penyerapan tenaga kerja, potensi konflik dengan masyarakat rendah, menumbuhkan lapangan usaha, menumbuhkan sektor formal dan informal, penguatan peran serta masyarakat.

Salah satu permasalahan yang ditimbulkan dari sampah adalah menurunnya estetika di sekitar tempat pembuangan sampah sehingga berpotensi menimbulkan konflik sosial dengan masyarakat yang ada di sekitarnya. Pengelolaan sampah yang tepat diharapkan dapat menumbuhkan kesadaran dan pola pikir masyarakat untuk selalu menjaga lingkungan serta terbentuknya masyarakat yang peduli terhadap permasalahan sampah.

\section{Conclusions}

Berdasarkan hasil penelitian ada pengaruh antara pendidikan ( $\mathrm{p}$ value $=0,006)$,infrastruktur ( $\mathrm{p}$ value $=0,003$ ), pengetahuan ( $\mathrm{p}$ value $=0,000$ ) dengan partisipasi masyarakat dalam pengelolaan sampah rumah tangga di Kecamatan Marpoyan Damai Kota Pekanbaru. Hasil analisis regresi logistik didapatkan bahwa variabel pendidikan memiliki nilai $p=0,048$ dan OR 2,888 y ang arti nya pendidikan memiliki 2 kali risiko terhadap pengelolaan sampah. Variabel infras truktur mem iliki nilai $p=0,001$ dan $0 R 6,838$ yang artinya infrastruktur memiliki 6 kali risiko terhadap pengel ol aan sampah. Variabel pengetahuan memiliki nilai $p=0,000$ dan $0 R$ 9,617 yang artinya pengetahuan

Received: 3 Agust 2020, Accepted : October 2020 - Jurnal Photon Vol.11 No.1

DOI : https://doi.org/10.37859/jp.v17i7.2089

PHOTON is licensed under a Creative Commons Attribution-ShareAlike 4.0 International 
memiliki 9kali risiko terhadap pengelolaan sampah.Dampak lingkungan dari pengelolaan sampah yang tepat yaitu menurunnya volume timbulan sampah serta kerusakan lingkungan. Secara ekonomi, saat ini belum ada nilai ekonomis terhadap pengelolaan sampah, selain masyarakat belum paham terhadap pengelolaan sampah yang mempunyai nilai ekonomis dengan 3R. Pengelolaan sampah yang tidak dapat memadai menyebabkan rendahnya tingkat kesehatan masyarakat sehingga masyarakat perlu mengeluarkan biaya lebih untuk berobat. Secara sosial, sebagian bes ar masyarakat belum peduli terhadap pengelolaan sampah dan walaupun ada pengelolaan sampah masih bersifat individual dan belum terorganisir secara terpadu.

\section{References}

Angell. (2011). Perilaku Konsumen Edisi ke 6 Jilid 1. Binarupa. Aksara

Artiningsih, N.A. (2008). Peran Serta Masyarakat dalam Pengelolaan Sampah Rumah Tangga. Il mu Lingkungan.

Asmawati. (2010). Studi tentang Pendidikan, Pengetahuan dan Tindakan Masyarakat Terhadap Pengelolaan Sampah Rumah Tangga di Desa Maccini Baji Kecamatan Matang Kabupaten Jenepunto. Fakultas Ilmu Kesehatan UIN Alauddin Makassar.

Bachtiar, H. Hanafi dan Rozikin. (2015). Pengembangan Bank Sampah Sebagai Bentuk Partisipasi Masyarakat dalam Pengelolaan Sampah (Studi pada Koperasi Bank Sampah Malang). Jurnal Administrasi Publik (JAP).

Badan Pusat Statistik Kota Pekanbaru. (2019). Kota Pekanbaru dalam Angka. Pekanbaru.

Cohen, U. (2011). Rural Development Participant. New York: Cornel University.

Departemen Pendidikan Nasional. (2005). Kamus Besar Bahasa Indonesia. Jakarta: Balai Pustaka.

Dwiyanto, B.M. (2011). Model Peningkatan Partisipasi Masyarakat dan Penguatan Sinergi dalam Pengelolaan Sampah Perkotaan. Jurnal Ekonomi Pembangunan Vol. 12 No.2.

Hartati. (2010). Faktor-Faktor yang Mempengaruhi Partisipasi Masyarakat dalam Pengelolaan Sampah Rumah Tangga. Jurnal Ilmu Lingkungan Vol. 2 No. 2.

Hasibuan, R. (2016). Analisis Dampak Limbah/Sampah Rumah Tangga Terhadap Pencemaran Lingkungan Hidup. Jurnal Ilmiah Advokasi Vol.4 No.1. ISSN 2337-7216.

Hidayat. (2007). Metode Penelitian Keperawatan dan Teknik Analisa Data. Jakarta. Salemba Medika. Ikhsandri. (2014). Kajian Infrastruktur Pengolahan Sampah di Kawasan Berkembang Jakabaring Kelurahan 15 Ulu Kota Pal embang. Jurnal Teknik Sipil dan Lingkungan Vol. 2 No.1. ISSN: 2335-374X.

Kamal, F. (2009). Hubungan Antara Tingkat Pengetahuan dan Sikap Ibu Rumah Tangga Tentang Pengelolaan Sampah dengan Perilaku Pembuangan Sampah pada Masyarakat Sekitar Sungai Beringin di RW 7 Kelurahan Wonosari Kecamatan Ngaliyan Kota Semarang. Ilmu Kesmas Universitas Negeri Semarang.

Marliani, N. (2014). Pemanfaatan Limbah Rumah Tangga (Sampah Organik) sebagai Bentuk Implementasi dari Pendidikan Lingkungan Hidup. Jurnal Formatif Vol. 4 No. 2 ISSN 2008 351X.

Menteri Pekerjaan Umum RI. (2006). Peraturan Menteri Pekerjaan Umum No. 21/PRT/M/2006. Kebijakan dan Strategi Nasional Pembangunan Pengelolaan Persampahan (KSNP-SPP).

Mifbakhuddin. (2010). Gambaran Pengelolaan Sampah Rumah Tangga Tinjauan Aspek Pendidikan, Pengetahuan dan Pendapatan Perkapita di RT 6 RW 1 Kelurahan Pedurungan Tengah Semarang. Jurnal Kesehatan Masyarakat Indonesia.

Mulasari. (2012). Hubungan Tingkat Pengetahuan dan Sikap Terhadap Perilaku Masyarakat dal am Mengelola Sampah di Dusun Padukuhan Desa Sidokarto Kecamatan Godean Sleman Yogyakarta. Kesehatan Masyarakat.

Munawir. (2015). Bank Sampah Upaya Pemberdayaan Masyarakat dan Penanganan Lingkungan. Jurnal Buletin Bisnis dan Manajemen Vol. 1 No.1 ISSN: 2442-855X.

Received: 3 Agust 2020, Accepted : October 2020 - Jurnal Photon Vol.11 No.1

DOI : https://doi.org/10.37859/jp.v17i7.2089

PHOTON is licensed under a Creative Commons Attribution-ShareAlike 4.0 International 
Notoatmodjo. (2012). Promosi Kesehatan dan Ilmu Perilaku. Jakarta. Rineka Cipta.

Nurhafni. (2016). Partisipasi Masyarakat Terhadap Efektivitas Pengelolaan. Jurnal Ilmu Lingkungan. ISBN 978-979-792-675-5.

Nursalam. (2008). Konsep dan Penerapan Metodologi Penelitian. Jakarta. Salemba Medika.

Rahman, A. (2013). Perilaku Masyarakat dalam Pengelolaan Sampah Rumah Tangga (Studi Kasus di Kelurahan Pasar Sarolangun). Jurnal Bina Praja Vol. 5 No.4.

Raharjo. Santoso, T. (2015). Kearifan Lokal, Keberfungsian Sosial dan Penanganan bencana. Departemen Kesejahteraan Sosial. Bandung.

Riyanto, B. (2013). Kapita Selekta Kuesioner Pengetahuan dan Sikap dalam Penelitian Kesehatan. Jakarta. Salemba Medika.

Sari, M. (2017). Pengetahuan, Sikap dan Pendidikan dengan Perilaku Pengelolaan Sampah di Kelurahan Bener Kecamatan Tegalrejo Yogyakarta. Jurnal Medika Respati Vol. 12 No.2 ISSN 1907-3887.

Setyaningrum, I. (2015). Karakteristik Peningkatan Pengelolaan Sampah oleh Masyarakat Melalui Bank Sampah. Jurnal Teknik PWKVol. 4 No.2.

Slamet. (1994). Pembangunan Masyarakat Berwawasan Partisipasi. Surakarta: UNS Press.

Soesanto. (2018). Optimalisasi Perencanaan Infrastruktur Pengelolaan Sampah dengan Pemod el an Program Linier (Studi Kasus Pengelolaan Sampah di Kabupaten Sragen). Tesis Teknik Sipi l Universitas Muhammadiyah Surakarta.

Sudiran. (2005). Instrumen Sosial Masyarakatan Karangmumus Kota Samarinda dalam Penanganan Sampah Domestik. Makara Sosial Humaniora. Vol. 9 No.1.

Sugiyah. (2001). Partisipasi Komite Sekolah dalam Penyelenggaraan Rintisan Sekolah Bertaraf Internasional di Sekolah Dasar Negeri IV Wates Kabupaten Kulon Progo. Tesis PPs UNY.

Sugiyono. (2008). Statistik Untuk Penelitian. Bandung. Alfabeta.

Sumantri. (2015). Potensi Daur Ulang dan Partisipasi Masyarakat dalam Pengelolaan Sampah di Kecamatan Jabon Kabupaten Sidoarjo. Jurnal Teknik ITS Vol. 4 No.1.

Surbekti, S. (2010). Pengelolaan Sampah Rumah Tangga 3R Berbasis Masyarakat. Prosiding Seminar Nasional Sains dan Teknologi.

Tilaar, H. (2009). Kekuasaan dan Pendidikan: Kajian Manajemen Pendidikan Nasional dalam Kekuasaan. Jakarta. Rineka Cipta.

Yulianti, R. (2000). Efektivitas Metode Peran Serta Masyarakat dalam Pembangunan dan Pengelolaan Limbah Perkotaan. Semarang. Fakultas Teknik Universitas Diponegoro.

Received: 3 Agust 2020, Accepted : October 2020 - Jurnal Photon Vol.11 No.1

DOI : https://doi.org/10.37859/jp.v11i7.2089

PHOTON is licensed under a Creative Commons Attribution-ShareAlike 4.0 International 